NBER WORKING PAPER SERIES

\title{
WHEN DO FIRMS HIRE LOBBYISTS? \\ THE ORGANIZATION OF LOBBYING \\ AT THE FEDERAL COMMUNICATIONS COMMISSION
}

\author{
John M. de Figueiredo \\ James J. Kim \\ Working Paper 10553 \\ http://www.nber.org/papers/w10553 \\ NATIONAL BUREAU OF ECONOMIC RESEARCH \\ 1050 Massachusetts Avenue \\ Cambridge, MA 02138 \\ June 2004
}

We wish to thank Jim Alt, Scott Masten, and an anonymous referee for helpful comments. de Figueiredo acknowledges the generous financial support of the Industrial Performance Center at MIT. The views expressed herein are those of the author(s) and not necessarily those of the National Bureau of Economic Research.

(C)2004 by John M. de Figueiredo and James J. Kim. All rights reserved. Short sections of text, not to exceed two paragraphs, may be quoted without explicit permission provided that full credit, including (C) notice, is given to the source. 
When Do Firms Hire Lobbyists? The Organization of Lobbying at the Federal Communications Commission

John M. de Figueiredo and James J. Kim

NBER Working Paper No. 10553

June 2004

JEL No. L5, K0, H1

\section{$\underline{\text { ABSTRACT }}$}

This paper examines the explanatory power of transaction cost economics to explain vertical integration decisions for lobbying by firms. We examine 150 lobbying contacts at the Federal Communications Commission (FCC) on the issue of payphone compensation for dial-around calls. When firms lobby on topics that are highly firm-specific and prone to sensitive-information leakage, they are more likely to use employees to lobby the FCC. However, when topics arise that are more general to the industry and do not include sensitive information, firms are more likely to use outside counsel to lobby the FCC.

John M. deFigueiredo

MIT, Sloan School of Management

50 Memorial Drive

Cambridge, MA 02142-1347

and NBER

jdefig@mit.edu

James J. Kim

Columbia University

Graduate School of Business

3022 Broadway, 111 Uris Hall

New York, NY 10027

jakim04@gsb.columbia.edu 


\section{Introduction}

Vertical integration has traditionally been studied with respect to investment decisions in markets. Transaction cost economics, one of the seminal theories of vertical integration, describes how boundedly rational and opportunistic parties engage in transactions in an incomplete contracting environment. When specific investments are required or other contractual hazards arise in this environment, arms length contracting will likely break down, and some form of governance, usually vertical integration (or equity participation), will be required to consummate transactions (Williamson 1975, 1985, 1996).

Over six hundred empirical studies have demonstrated the veracity of the transaction cost economics theory in a variety of settings (Klein and Shelanski 1995; Boerner and Macher 2002). One area in which there is much less empirical work is in the application of transaction cost economics to the non-market strategy of the firm. Non-market strategies are the set of actions firms employ in institutions other than the market—such as the media, the government, the society — that are designed to enhance the profitability of the firm (Baron 1996, 1999). These types of institutions can have a profound effect on a company's income. Thus, the firm must configure its activities in these institutions strategically if it is to enjoy favorable coverage, regulation and legislation, and thus secure a competitive advantage.

This paper examines the power of the transaction cost framework in explaining vertical integration decisions in non-market settings. In particular, the paper explores whether the organization of lobbying by firms conforms to the transaction cost economics logic in the presence of the potential leakage of sensitive, firm-specific information. We examine lobbying by firms at the Federal Communications Commission (FCC) over the issue of payphone compensation for dial-around calls. We have collected data on each individual lobbying contact 
made at the FCC on this issue (nearly 150 lobbying contacts) and coded its content. More importantly, with these data, we can examine whether firms used lobbyists-for-hire or internal resources when lobbying the FCC in this issue area.

This paper shows that when firms lobby on topics that are highly firm-specific and have the potential for information leakage, they are more likely to use employees and managers to lobby the FCC on these issues, ceteris paribus. However, when topics arise that are less sensitive or require knowledge that is general to the industry, firms are more likely to use outside counsel to lobby the FCC, ceteris paribus. These findings are robust when we control for firmtype, the position of the firm, the time in the lobbying cycle and potential alternative theories. The results reported here are consistent with the transaction cost framework being applied to the organization of lobbying by firms. Moreover, it suggests that application of the transaction cost framework to the non-market activities of the firm may be an area ripe for further exploration.

The paper proceeds as follows. In the next section, we explain how transaction cost economics translates into the make-or-buy decisions for firms in lobbying. Section III describes the issues confronting interest groups at the FCC in payphone compensation. Section IV outlines the data and method. We report the results in Section V. In Section VI, we consider the robustness of our results. We conclude in Section VII.

\section{The Application of TCE to Non-Market}

The transaction cost approach to organizational issues is comparative in its analysis, emphasizing the benefits of alternative organizational choices. In its more standard economic applications, this approach addresses the "make or buy" decision — that is, the decision of the firm to either internalize production or to purchase goods and services on the market. This 
perspective suggests that in an effort to promote efficiency in firm governance, the objective for the firm is to match organizational forms (ranging from market to hierarchy) with the transactional "hazards" facing the firm in making agreements with others. The most important source of contracting hazards in early treatments of transaction cost economics was the need for relationship-specific investments (Klein, Crawford and Alchian 1978; Williamson 1985, 1996; Nickerson and Silverman 2004). More recent empirical and theoretical extensions of this work, however, have shown specific investments to be only one source of contractual hazards. Other concerns, such as appropriability hazards — the ability of firms to appropriate the returns from other firms' innovations and know how — have now been incorporated into the transaction cost framework (Teece 1986, Oxley 1997, de Figueiredo and Teece 1996).

In this paper we explore the leakage hazard—-the danger that sensitive, firm-specific information may leak out to markets and competitors—-which could be considered a subset of the broader appropriability hazard. In market contexts, the danger of outside employees walking away with sensitive information has long been recognized. Anderson $(1985,1988)$ recognized this in her analysis of the organization of marketing representatives, and firm decisions as to whether to use manufacturing representatives or direct sales forces. de Figueiredo and Teece (1996) discussed this problem in the context of companies in fast evolving industries. Oxley (1997) made this concern explicit with her analysis of high-technology international alliances. Finally, de Figueiredo and Tiller (2001) explored the leakage problem in the context of lobbying. All of these papers highlight the possibility of information leakage occurring in a contractual relationship. The consensus of these papers is that the response of the firm is to move to an internal organizational structure when this hazard is present 
In the specific area of lobbying, there is an anecdotal record that supports the idea that leakage of sensitive information by external lobbyists is a substantial concern for politically active firms. In lobbying the FCC for approval of the Time Warner-AOL merger, for example, AOL acted to diversify the risk of sensitive information leaks by hiring multiple lobbyists to tackle separate parts of the core issue. Prior to the merger, AOL's in-house lobbying group consisted of eight internal employees and four external firms. Although these four lobbyists-forhire were retained in 2000, the bulk of the merger lobbying occurred through newly hired firms like Wiley, Rein, \& Fielding and Skadden Arps. Time Warner also followed suit, bringing on Louis Dupart from Fleishchman \& Walsh to address general antitrust concerns. Since both Fleischman \& Walsh and Wiley Rein had represented Bell Atlantic/Verizon for several years - a traditional opponent of increasing cable company telecommunications offerings - most of the lobbying through these firms involved general overall consumer benefit and procedural issues such as the actual application for transfer of control. Sample informational filings from these firms to the FCC included SEC 8-K forms for Time Warner Inc. for 1999 and new corporate structure charts. Overall, only half of Time Warner's lobbying contacts were made through Fleischman or Wiley. On many occasions, AOL-TW lobbied directly on more sensitive and specific issues such as the status of AOL's Advanced Instant Messaging Service and technical issues like unused cable capacity.

Despite the best efforts of the AOL, Time Warner and the FCC, firm specific information and details of the merger were leaked to opponents. Lobbying firm Verner Liipfert, hired by the Disney Corporation, obtained sensitive documents that they then leaked to other Disney staff. ${ }^{1}$ Although the FCC banned Disney and its lobbyists from reviewing private data for six weeks, further AOL-TW internal documents were obtained and improperly disclosed. Obtaining this 
information gave Disney a platform on which to build an argument that stalled the proposed merger in the Federal Trade Commision and before the European Commission. ${ }^{2}$

Although more systematic research on the role of appropriability and leakage hazards in procurement organization has been done, very little research has examined the governance of lobbying activities. We are aware of only two studies examining the lobbying behavior of firms within a transaction cost framework. The first examines how the asset base of the firm affects the lobbying behavior of the firm (Alt et al 1999). In examining Norwegian firm lobbying behavior, Alt et al argue that firms whose assets are more industry-specific and less mobile are more likely to lobby for subsidies from the government when faced with increased international competition. Moreover, the greater the specificity of a firm's assets (measured by R\&D intensity and job mobility) the greater the likelihood of joint lobbying by both management and labor. A second paper (de Figueiredo and Tiller 2001) examines lobbying at the transaction level. This work, examining appropriability hazards, finds that when firms lobby they choose their lobbying agent so as to protect sensitive information. When there is sensitive information changing hands in the lobbying process, firms will choose to use their own agents, as opposed to trade associations.

The current paper follows the approach of the second paper by asking how interest groups organize their lobbying effort in an environment with a high probability of information leakage. This paper, however, is more general than the previous de Figueiredo-Tiller paper in three ways. First, rather than examine appropriability hazards in a general way, we explore in a very detailed way how the firm organizes its activities in the presence of leakage hazard. We conduct a detailed econometric analysis of one issue where fine-grained panel data can be brought to bear. Second, while the previous paper was only able to make a distinction between 
trade association and "firm" — where "firm" is both a contractor and employee, this paper makes a distinction in the more classic Williamson sense- between the lobbyist as contractor and the lobbyist as employee. ${ }^{3}$ Third, whereas the previous paper examined the proportion of lobbying on different issues that was trade association vs. firm, this paper examines the organization of each lobbying contact and how it is configured.

With respect to the hazard of information leakage, transaction cost economics has a very clear prediction: The greater the hazard of leakage, the more likely the firm is to take precautions to prevent this dissemination of sensitive information. The response in such cases is likely to be vertical integration; that is, lobbying will be performed by an employee of the corporation. Thus, if the leakage hypothesis is correct, firms will conduct lobbying that may result in leakage of sensitive, firm-specific knowledge "in-house" and employ hired guns for lobbying that involves information which is more general or contains little or no firm-specific information. In Section IV, we test this hypothesis in the context of the payphone compensation issue that first came before the Federal Communications Commission in 1996.

\section{Payphone Compensation}

\subsection{Background and Timeline}

When a consumer makes a 1-800 call from a payphone, she normally does not deposit money into the payphone. A long distance carrier specified by the payphone owner carries the call to its destination (such as an airline reservation agent). These 1-800 calls, calling card calls, and 10-10-XXX calls, are known as dial-around calls and have historically provided no revenue for the payphone owner, that is, the owner of the physical payphone was required to allow the use of his equipment for free for these calls. 
However, Congress, in the Telecommunications Act of 1996, directed the Federal Communications Commission to establish rules promoting competition in the payphone marketplace. Specifically, the Telecom Act required the FCC to set a fair per-call compensation rate for all dial-around calls made from payphones. The FCC's rate decision could result in a transfer of up to $\$ 40$ million from long distance inter-exchange carriers (IXCs) such as AT\&T, MCI, and Sprint (who carried these "free calls") to payphone operators, such as the Regional Bell Operating Companies (RBOCs) and small independents (who owned the payphones).

The FCC initiated formal debate on the issue in June 1996 with the issuance of a Notice of Proposed Rulemaking (NPRM) on Payphone Compensation, giving it Docket \#CC 96-142. The NPRM called for public comment on three issue areas that the FCC would consider making rulings on: 1) the amount of compensation payphone owners would receive for carrying these dial-around calls, 2) the method of payment for these dial-around calls, and 3) the method of tracking the number of these dial-around calls.

Following three months of lobbying (described in the next section), the FCC issued its first decision on September 20, 1996 with the First Report and Order. Employing a marketbased compensation mechanism, the FCC pegged the compensation rate to the local coin fee at $\$ 0.35$ per call. Multiplied by an average of 131 dial-around calls per month, interexchange carriers were required to pay a combined fee of $\$ 45.85$ for each payphone on a monthly basis. Although the Order was viewed as a victory for payphone owners, large payphone service providers including the Baby Bell companies sought a higher compensation rate and a broader definition of dial-around calls. ${ }^{4}$ A coalition of telecommunications companies brought their case before the U.S. Court of Appeals. Ruling on July 1, 1997, the Court vacated the FCC's 
compensation scheme with the reasoning that the Commission had acted "arbitrarily" and failed to justify the linking of the compensation rate to the market coin-call rate. ${ }^{5}$

Over the next two years, the forum for payphone compensation would continuously shift between the FCC and the Court of Appeals. In the FCC’s October 1997 Second Report and Order, the Commissioners used a "top-down methodology" to determine that dial-around calls were $\$ 0.066$ cheaper than coin calls, implying a compensation rate of $\$ 0.284$ (\$0.35 - \$0.066). Dissatisfied with the high rate, MCI, who advocated $\$ 0.12$, chose to challenge the matter for a second time before the Court of Appeals. The Court again found the FCC's top-down approach to be unjustified, and remanded the decision back to the FCC in May $1998{ }^{6}$

A third round of FCC lobbying yielded the FCC’s Third Report and Order, issued on January 28, 1999. The Commissioners decided to employ a "bottom-up" methodology that built a cost-based compensation rate up from zero. The new rate of $\$ 0.24$ would continue to be in place in the absence of a private agreement between the payphone owners and IXCs. Calling card operators and IXCs would again protest the FCC's Third Order before the Court of Appeals. However, the Court would uphold the Commission's decision in June 2000. ${ }^{7}$

\subsection{Payphone Compensation Issue Lobbying}

As noted earlier, Docket CC96-128 covered a number of issues. Three issues are particularly relevant to our analysis: compensation method, compensation amount and InterLATA issues. ${ }^{8}$ Lobbying over compensation method involved interest groups pushing different mechanisms for a compensable call. For example, the small IXCs advocated a "calling party pays” approach, where consumers deposited coins for 1-800 calls, in lieu of the “interexchange carrier pays” system of reimbursement supported by the RBOCs and large IXC 
companies. A third plan was offered by paging companies, who argued that the compensation method should take the form of increased fees on subscriber line charges. This issue involved very little sensitive information or firm specific knowledge. Rather, lobbying tended to focus on industry-wide issues such as the impact of various calling schemes on different segments on the industry, national payphone fraud numbers or the total number of payphone calls in a geographic region. Thus, compensation method lobbying focussed on information at the industry level. This would map into "generic" knowledge in the transaction cost economics framework.

The second area of lobbying was for the actual per-call compensation amount and the equation used to determine it. While the FCC initially supported a flat rate reimbursement scheme, the IXCs backed a marginal cost-based rate. MCI initially argued that this amount should be $\$ .083$ per call. The RBOCs and independent payphone operators vigorously opposed this approach and instead advocated a rate based on market-based proxies. As evidence, the RBOCs provided studies and depositions concluding that the appropriate per-call compensation amount should be $\$ .81$ to $\$ .90$. Unlike compensation method lobbying, the compensation amount debate involved the transfer of very sensitive, firm specific information. RBOCs, IXCs and independent payphone service providers all offered the Commissioners detailed information about their firms, their strategies and their costs. Operational and logistical information from payphone operators also aided regulators in determining a fair compensation equation. Oral presentations and meetings allowed lobbyists to field questions from regulators on these topics. Much of the information involved in lobbying over this payphone compensation amount was thus competitively sensitive.

The third area over which there was lobbying was interLATA rights. This issue dealt with the rights of the RBOCs to negotiate with location providers (such as restaurants and 
airports that rent their space to the payphone operators) on the carriers providing interLATA long-distance service from payphones on its premises. While independent payphone operators could receive a commission from IXCs for interLATA operator service calls, RBOCs had not been afforded this option. Opponents feared that granting RBOCs this right would stifle competition, especially in areas where RBOC payphones controlled over $80 \%$ of the market. Inasmuch as the FCC's goal was to assess both the micro and macro level impact of allowing RBOCs to negotiate with IXCs, lobbying over interLATA rights likely involved both firmspecific and general industry information and may, thus, be considered "mixed" or "intermediate" in the level of sensitive information involved relative to compensation amount and compensation method.

\section{Data}

The empirical setting for the paper is lobbying of the Federal Communications Commission (FCC). The FCC is charged with regulating the telecommunications sector and has actively promulgated rules and regulations governing market actions of companies. The payphone compensation issue falls under the jurisdiction of the Common Carrier Bureau, the division of the FCC run by bureaucrats that reports to the five-member Commission. Before the FCC renders a decision on a docket, there is a formal and informal comment procedure for the parties potentially affected. The Code of Federal Regulations and FCC Guidelines establish a set of formal procedures that must be followed to comment on, or challenge, an FCC ruling. The informal procedure is a bit more opaque. Parties are permitted to make ex parte presentations to the FCC. These written or oral presentations can be to any official within the FCC, from the commissioners who make the final rulings to the industry-level bureau officials, experts who 
help craft the ruling for the Commission (de Figueiredo and Tiller 2001). Ex parte contacts by the telecommunications industry constitute the lobbying activities we examine here.

Ex parte contacts, as a measure of lobbying, have several attractive properties for empirical research of this type. First, because all contacts are required to be reported, there is not a sample selection bias problem. Second, the Secretary of the FCC provides uniform and consistent information on each ex parte presentation, minimizing the problem of missing and temporally inconsistent data. Finally, all contacts relate to a particular regulatory issue before the FCC and are reported as such. This allows us to investigate each and every instance of this primary form of lobbying.

In Figure 1, we present the amount of lobbying that occurred on each day during the entire lobbying cycle (1996 to 2000). Each bar represents the number of ex parte presentations that occurred on that day. What is evident is that there are spikes before each order is issued. This suggests that the timing of lobbying tends to be concentrated just before a decision is made by the FCC. Figure 2a presents number of contacts in the first lobbying cycle by the target of the lobbyists—-the bureaucrats in the Common Carrier Bureau or the Commissioners. It shows that lobbying at the Commissioner level is concentrated just before orders are issued by the Commission. Finally, Figure 2b presents the number of contacts that used a lobbyist-for-hire (non-integrated) versus employee lobbyist (integrated). It shows no obvious pattern.

To test the predictions of the theory, we have collected, reviewed and read every ex parte contact on CC96-128: Payphone Compensation. The FCC reports 1,003 ex parte contacts on this issue from June 27, 1996 to December 20, 2000. After we remove the data that are incomplete or are coded in the FCC database incorrectly, we obtain 934 usable contacts over the entire period. Our focus, however, is the first period—the time between the NPRM and First Report 
and Order issued by the FCC on this docket. In choosing this time frame, we eliminate complications that might arise when a court intervenes in a regulatory proceeding. ${ }^{9}$ (In later robustness checks, we will use different sample frames.) From the time of the NPRM to the first report and order there are 150 usable lobbying contacts $(n=150)$ covering 105 days. $^{10}$

In this statistical analysis, the unit of observation is an ex parte lobbying contact. A lobbying contact is an $(i, j, t)$ triplet where interest group $i$ contacts regulator $j$ on the CC 96-128 docket on date $t$. For each lobbying contact, we code a variety of information. The dependent variable of interest is the integration decision: does the interest group hire an outside lawyer (1) or does the interest group use its own counsel (0) for lobbying?

From Section III of the paper, we use our understanding of the issues to identify the degree of firm-specific, sensitive information required by lobbying agents. Specifically, we code four dummy variables for issue type: COMPENSATION AMOUNT, INTERLATA, COMPENSATION METHOD and OTHER. As discussed in Section III, we expect lobbying over COMPENSATION AMOUNT to require relatively more firm-specific, sensitive knowledge and thus be more likely to be performed by employees; lobbying over COMPENSATION METHOD to require industry expertise but relatively little firm-specific knowledge, thereby favoring external lobbyists; and INTERLATA lobbying to involve a mixture of firm-specific knowledge and industry expertise, resulting in an intermediate or indeterminate degree of integration. Finally, we include a dummy variable, OTHER, where a lobbying contact involved other issues of relatively minor importance. As discussed below, a given lobbying contact may have involved a single or as many as three issues.

In addition to the issue dummies above, we include a set of variables as controls for other possible influences on the lobbying decision. We see in Figure 1 that there tend to be spikes in 
the amount of lobbying late in the lobbying cycle in the days before the report and order. We include a variable called DAYS that measures the number of days since the NPRM to control for the possibility that, as the issue gets closer to resolution, interest groups employ more internal lobbyists who may press the firm's case harder closer to the deadline. Related to this, we include a variable called COUNT, which is the count of lobbying contacts on a given day, to control for the possibility that certain days may be of particular importance to the lobbyists.

We see in Figure 2 that there is a cycle for working up the hierarchy of the FCC in lobbying as well. Early contacts tend to be primarily at the Bureau level. Late in the cycle, the Commissioners themselves entertain lobbying. To this end, we include a variable called COMMISSIONER that is equal to 1 if the interest group is lobbying a Commissioner or his staff, and 0 otherwise. Like the DAYS variable, one might expect that executives lobby the commissioners rather than sending in their lobbyists-for-hire.

Finally, we include dummy variables, RBOC and IXC, for Regional Bell Operating Companies and the large Interexchange Carriers (AT\&T, MCI, Sprint), respectively, and POSITION for the position the firm takes $(=1$ if $>\$ 0.35$; $=0$ if $<\$ 0.35$ ) on the payphone compensation issue. Because the Bell companies and interchange carriers have large Washington offices, we expect that these large firms may be more likely to use internal lobbyists.

Table 1 reports descriptive statistics for the sample. ${ }^{11}$ The Table shows that $30 \%$ of lobbying contacts employed lawyers while the remainder used internal employees or managers. Interestingly, 85\% of lobbying was done by those interest groups that prefer a high compensation rate. A large amount of lobbying was done on the compensation amount, interLATA, compensation method, and other issues—-59\%, 41\%, 64\%, and 4\% of all lobbying, respectively. The percentages sum to more than $100 \%$ because the lobbying categories are not mutually 
exclusive. Nearly $62 \%$ of all lobbying contacts covered multiple issues, with lobbying over compensation method and compensation amount, jointly being the most frequent (38\% of all lobbying), followed by compensation method and interLATA (20\%), and compensation amount and interLATA (19\%).

\section{Empirical Results}

Because the dependent variable is dichotomous, we estimate the model using a probit model. The dependent variable is coded as 1 if the lobbying contact was made by a manager or employee and 0 if by a hired lobbyist. Hence, a positive (negative) coefficient means that an increase in the corresponding variable increases (decreases) the probability that lobbying will be performed by an employee or manager rather than an outside lobbyist. The standard errors, reported in parentheses below the coefficient estimates, are corrected for clustering by interest group. Statistical significance of the coefficient estimates is presented at the $99 \%, 95 \%$ and $90 \%$ level of significance for two-sided t-tests.

The first two columns of Table 2 report results for two specifications of the model using the 150 lobbying contacts in the 105-day period between the Notice of Proposed Rulemaking (NPRM) and the First Report and Order. Model 1 examines the probability of integration as a function of lobbying issues only. The coefficients on the three main issue variables are all statistically significant and their signs and relative magnitudes are consistent with the theory; contacts involving lobbying on compensation amount are most likely, and contacts involving lobbying on compensation methods are least likely, to use internal lobbyists. The significant positive coefficient on INTERLATA indicates that lobbying contacts involving interLATA issues are somewhat more likely to be integrated than contacts not involving that issue, but the 
effect of that issue on the probability of integration is intermediate between COMPENSATION AMOUNT and COMPENSATION METHOD, as we anticipated.

To assess whether the differences in integration among issue types might reflect other factors potentially influencing lobbying organization, we re-ran the estimation with the set of control variables. ${ }^{12}$ The inclusion of the control dummies significantly improves the model's predictive power; a log-likelihood ratio test statistic comparing Model 1 and Model 2 is 15.3, above the $X^{2}{ }_{(6)} 95 \%$ critical value of 14.2 . As in Model 1 the coefficient on COMPENSATION AMOUNT in Model 2 is positive and statistically significant (at the 99\% level), and the coefficient on COMPENSATION METHOD is negative and statistically significant (also at the 99\% level), both as predicted. Unlike Model 1, the coefficient on INTERLATA in Model 2 is not significantly different from zero, indicating that, after controlling for other factors, inclusion of interLATA issues in a lobbying contact neither increases nor decreases the probability that that contact will be made by internal lobbyists. Again, this is consistent with the theory's predictions regarding the relative likelihood of integration among issues. (The theory, obviously, offers no prediction for the effect of miscellaneous category OTHER.) Thus, overall, the signs and relative magnitudes of the coefficients on the issue categories are statistically significant and consistent with the theory.

To gauge the economic significance of the issue types on the likelihood of integration, we use the results of Model 2 to calculate the probability of integration with each issue dummy in turn set equal to one and the control variables at their mean values. First, the probability of using internal lobbyists when lobbying for INTERLATA issues (alone) is 0.81, a fraction not significantly different (as indicated by the t-statistic on the corresponding coefficient) from the sample mean of 0.71 . When the issue is COMPENSATION METHOD, by contrast, the 
probability of using an internal lobbyist falls to 0.26 . (The probability of using an internal lobbyist for the OTHER category is comparable at 0.28.) Finally, when lobbying on COMPENSATION AMOUNT, the probability of internal lobbying rises to 0.98 , a full seventy percentage points higher than the probability for COMPENSATION METHOD lobbying.

Among the other results, we find that lobbying of commissioners (COMMISSIONER) is more likely to be done by managers or employees of the company than by outside lobbyists at a statistically significant level. Considering a discrete change from 0 to 1 of the COMMISSIONER variable, while holding all other variables, including the issue-type dummies, at their means, lobbying a COMMISSIONER results in a 17 percentage point increase in the probability of internal lobbying. Executives often meet with the Commissioners in the lobbying process to outline strategic issues related to the issues at hand. We also find that the more lobbyists that lobby the Commission on a given day (COUNT), the more likely we are to see outside lobbyists used. The negative coefficient on COUNT means that, at the mean, an additional ex parte presentation increases the probability that firms will use lobbyists-for-hire by 2 percentage points. Neither DAYS nor POSITION have a significant effect on the organization of lobbying in Model 2.

Finally, the results indicate that companies that had been part of the Bell system (RBOC) are more likely than other interest groups to use internal lobbyists (by 27 percentage points holding all other variables at their mean). The coefficient for the large interexchange carriers (IXC), while negative, is not statistically significant. (In later regressions, we find that both RBOCs and IXCs tend to favor inside lobbyists at statistically significant levels, and we offer an explanation as to why this is.) 
Our interpretation of the initial results in Model 2 is that the transaction cost theory and the leakage hypothesis finds substantial support in the coefficients for the issue variables. Not only are the coefficients signed as predicted and statistically significant, but the effect of variables on the probability of integration is substantial.

\section{Robustness}

To examine the robustness of the results, we present also in Table 2 estimates of the model using observations for lobbying contacts subsequent to the First Order and Report. The first sample frame we consider is the reconsideration period. As noted in footnote 4, after the first order issued by the FCC, a number of firms petitioned for the Commissioners to reconsider their decision. This reconsideration process lasted approximately 60 days and involved a noticeable amount of lobbying. In Model 3 on Table 2, we replicate Model 2 but include only the 47 lobbying contacts between the first order and the first order under reconsideration. Again, all standard errors are clustered on interest group. Although a number of variables must be dropped from this specification because of the small number of observations creating an "emptycell” problem (OTHER, IXC, and COMMISSIONER) or creating a lack of variation in the independent variable (INTERLATA), the two key variables, COMPENSATION AMOUNT and COMPENSATION METHOD, remain. The estimated coefficients on these variables are positive and negative, respectively, as predicted by the theory, but are not statistically significant, a finding that may be due to the small sample size.

The second sample frame we consider is the post-order and pre-trial intervals. This allows us to examine whether there is systematically different lobbying in the pre-trial interval and post-trial interval. In Model 4, we consider only those intervals between the FCC decisions 
and the trials (in all three rounds). Observations between the trial and the FCC decision are omitted. The results are presented in Model 4 of Table 2. The coefficient on COMPENSATION METHOD is still negative and statistically significant at the 99\% level. The coefficient on COMPENSATION AMOUNT is positive, as expected, but does not reach the standard levels of statistical significance.

The third sample frame we consider is the full sample-including all three rounds of FCC orders and trials. For reasons elucidated in Section IV, we originally limited our analysis to the first lobby cycle in order to exclude the influence of court decisions from the analysis. To assure that our previous findings are not an artifact of this sample frame, however, we examine here whether the results are robust over the full set of pre-trial and post-trial lobbying contacts.. Model 5 in Table 2 reports results using the same specification as Model 2 using the entire sample of lobbying $(\mathrm{n}=934)$, which includes all lobbying from date of the NPRM to the Third (and Final) Report and Order 972 days later. Overall, the results are similar although the statistical significance of some of the coefficients changes. Most important, the COMPENSATION AMOUNT and COMPENSATION METHOD variables have coefficients that are signed as in Model 2 and are statistically significant at the 90\% and 99\% level respectively. Their magnitudes, however, are only about one-third of their values in Model $2 .^{13}$ Nevertheless, on the whole, Model 5 conforms to the expectations of TCE.

Finally, Model 6 repeats the estimation in Model 5 but includes time period dummies for each lobby interval. Of the added variables, only the coefficient on the RECONSIDERATION dummy variable is statistically significant at the $90 \%$ level or greater; the remainder of the results are very similar to Model 5. On the whole, the supplementary regressions generally support the original findings. ${ }^{14}$ The coefficients of interest maintain their sign and retain their 
statistical significance (in all but one case), though, in some instances, their magnitudes are smaller.

\section{Conclusion}

This paper has used a dataset on individual lobbying contacts at the Federal Communications Commission to show that firms follow the transaction cost logic when organizing their lobbying effort. On issues where there is a potential for a high degree of leakage of sensitive, firm-specific information, firms tend to use their own employees for lobbying. However, on issues that do not encounter this leakage hazard, firms tend to outsource this lobbying to lobbyists-for-hire. The evidence also indicates that the use of internal lobbyists is greater for large firms and when firms are lobbying commissioners (as opposed to FCC bureau level employees).

Admittedly, issue type is an imperfect proxy for the degree of potential leakage, and it is possible that our issue variables capture some other factor affecting the organization of lobbying activities. Generic information of the type likely to be associated with lobbying on compensation method, for instance, may be fairly easy to summarize and convey to an external agent, whereas explaining firm-specific information to an external lobbyist might be time consuming and may require on-going advising from the firm at substantial cost. Although we cannot statistically rule out this alternative explanation with our data, the description of the AOL-Time Warner merger in section 2 provides anecdotal evidence that leakage of sensitive information by external lobbyists is a concern to industry players. Indeed, FCC Commissioners have acknowledged leaks of sensitive information as problematic in not only this case but more generally. ${ }^{15}$ 
Although transaction cost economics has made great strides in explaining the vertical integration of firms in market situations, studies that examine the application of the theory to non-market strategy generally, and lobbying in particular, are sparse. This paper, however, shows that the logic developed by Williamson nearly thirty years ago still has applicability today. In also suggests that the application of the transaction economics framework to issues such as lobbying, litigation and regulatory proceedings is likely a fruitful avenue for future research to follow. Given the novelty of the setting and the limitations of the data, further work is certainly warranted. 


\section{REFERENCES}

Alt, James E., Fredrik Carlesen, Per Heum, and Kare Johansen (1999), “Asset Specificity and the Political Behavior of Firms: Lobbying for Subsidies in Norway,” International Organization, 53, 99-116.

Anderson, Erin. (1985), “The Salesperson as outside Agent or Employee: A Transaction Cost Analysis,” Marketing Science, 4, 234-254.

Anderson, Erin (1988), "Determinants of Opportunistic Behavior: An Empirical Comparison of Integrated and Independent Channels," Journal of Economic Behavior and Organization, 9, 247264.

Baron, David P. (1996), Business and its Environment. Prentice-Hall: Englewood Cliffs N.J.

Baron, David P. (1999), “Integrated Market and Nonmarket Strategies in Client and Interest Group Politics,” Business and Politics, 1, 1-32.

Boerner, Christopher S., and Jeffrey T. Macher (2002), “Transaction Cost Economics: As Assessment of Empirical Research in the Social Sciences,” Georgetown University Working Paper. 
de Figueiredo, John M., and Rui J. de Figueiredo, Jr. (2002). “The Allocation of Resources by Interest Groups: Lobbying, Litigation, and Administrative Regulation,” Business and Politics 4(2): 161-181.

de Figueiredo, John M., and David J. Teece (1996), “Mitigating Procurement Hazards in the Context of Innovation,” Industrial and Corporate Change, 5, 537-559.

de Figueiredo, John M., and Emerson H. Tiller (2001), “The Structure and Conduct of Lobbying: An Empirical Analysis of Corporate Lobbying at the Federal Communications Commission,” Journal of Economics and Management Strategy, 10, 91-122.

Hojnacki, Marie (1997), “Interest Groups Decisions to Join Alliance or Work Alone,” American Journal of Political Science, 41, 61-87.

Kim, James J. (2000), “An Investigation of Regulatory Arena Lobbying,” Undergraduate Thesis, Department of Political Science, Massachusetts Institute of Technology.

Klein, Benjamin, R. A. Crawford, and A. A. Alchian. (1978), "Vertical Integration, Appropriable Rents, and the Competitive Contracting Process," Journal of Law and Economics, 12, 297-326.

Moshan, Brook, Marcy Lerner, Hussam Hamadeh, Mark Oldman, Tyya N. Turner, Vera Djordjevich, and Dina Di Maio (2002), Vault Guide to the Top 100 Law Firms. Vault Reports Inc.: New York. 
Nickerson, Jackson A., and Brian S. Silverman (2004). "Why firms want to organize efficiently and what keeps them from doing so: Evidence from the for-hire trucking industry," Administrative Science Quarterly, forthcoming.

Oxley, JoAnne (1997). “Appropriability Hazards and Governance in Strategic Alliances: A Transaction Cost Approach,” Journal of Law, Economics, and Organization, 13, 387-409.

Ross, Patrick (2000). "FCC Tries to Crack Down on Information Leaks,” CNET News, 12 October 2000.

Teece, David J. (1986), "Profiting From Technology Innovation," Research Policy, 15, 285-305.

Williamson, Oliver E. (1975), Mechanisms of Governance. The Free Press: New York.

Williamson, Oliver E. (1983), “Credible Commitments: Using Hostages to Support Exchange,” American Economic Review, 73, 519-60.

Williamson, Oliver E. (1985), The Economic Institutions of Capitalism. Free Press: New York.

Williamson, Oliver E. (1996), The Mechanisms of Governance. Oxford University Press: Cambridge. 


\section{ENDNOTES}

${ }^{1}$ Commissioner Gloria Tristani noted many companies seeking action at the commission are reluctant to surrender confidential information. "They say, 'We don't want to give them to you, they might get out.' I understand that thinking now" (Ross 2000).

${ }^{2}$ Driven by unauthorized nonpublic information transfers by external lobbyists during the merger proceedings, the FCC in October 2000 released an order outlining new rules prohibiting the disclosure of nonpublic information. (FCC Order: 00-365. Amendment of Section 19.735-203 And Addition of Section 0.458 of the Commission’s Rules Concerning Nonpublic Information). Prior to this order, rules did not exist addressing the steps taken by persons regulated by or practicing before the Commission who came into possession of written non-public information (including written material transmitted in electronic form).

${ }^{3}$ Hojnacki (1997) also examines whether interest groups join alliances or go alone, but does not examine whether interest groups contract lobbyists or use their own managers.

${ }^{4}$ The FCC reconsidered its decision, and issued a modified order on November 8, 1996.

${ }^{5}$ D.C. Circuit Court of Appeals in Illinois Public Telecom, et al vs. FCC (117 F.3d 555).

${ }^{6}$ D.C. Circuit Court of Appeals in MCI Telecommunications Corporation, et al vs. FCC (143 F.3d 606)

${ }^{7}$ D.C. Circuit Court of Appeals in American Public Communications Council et al v. FCC (FCC 215 F.3d 51).

8 The other issues were relatively minor in nature and included Flex-ANI technology, Flex-ANI waivers, interim compensation rates, and other issues.

${ }^{9}$ See de Figueiredo and de Figueiredo (2002) for an example of how courts can affect interest group behavior in regulatory agencies. 
10 There are actually 168 lobbying contacts in the first 105 days, but we can only determine the position taken by 150 of the contacts.

${ }^{11}$ Cross correlations between all but one set of the variables is 0.5 or below. POSITION and IXC have a cross-correlation of -0.77 .

12 If we include a variable for Multi-Issue lobbying, the coefficient on this variable is not statistically significant, and a log-likelihood ratio test suggests it adds little to the overall explanatory power of the regression. The coefficient on COMPENSATION AMOUNT increases by $50 \%$, while the coefficient on COMPENSATION METHOD decreases by $40 \%$. All coefficients retain their sign, and the remaining coefficients of Model 2 stay roughly the same in magnitude.

13 The only variable that has an effect different from that in Model 2 is IXC. Its coefficient is now positive and statistically significant. The change could be because the IXCs shifted lobbying strategy to use more of their own lobbyists in later rounds of lobbying. It could also be a result of their increased focus on litigation because the regulatory decision was so far from their preferences. Together, the coefficients on RBOC and IXC are consistent with the idea that larger firms that have substantial Washington offices are more likely to employ those offices in the lobbying effort than are smaller firms. The underlying reasons for both of these shifts (the diminished magnitude of the coefficients in the larger sample, and the move of IXCs to use more internal lobbying) may reside in the court decisions. As the courts reduced uncertainty around the scope of litigation, firms began to shift their lobbying strategies.

${ }^{14} \mathrm{~A}$ final robustness issues is the potential endogeneity of a right hand side variable. In particular, a contract lobbyist may be willing to put himself at risk of expropriation by the firm (and make the specific investments) if the fee he is paid by the firm is sufficiently high. That is, 
to the extent that the expropriation hazard is priced into the wage rate, then markets may obtain even in the presence of specific investments and one-sided exposure. We cannot observe the prices law firms charge to clients for services. If we assume the prestige of the firm is correlate with the average rate it charges, we can measure prestige as a proxy for wages. We then obtained a prestige rating of the law firms (Moshan et al 2002), and code a dummy variable equal to one if the law firm is ranked in the top 100 in prestige and zero otherwise. When we run a regression of the prestige on the specificity variables, conditional on a law firm being used, we find that prestigious law firms are 34 percentage points more likely to represent firms in high specificity situations (COMPENSATION AMOUNT) than are non-prestigious law firms. This then confirms some of the intuition that labor markets can help to price out differentials in the specific investment. However, the results from Table 2 suggest that the integration (make-orbuy) logic of transaction cost economics continues to dominate the result.

${ }^{15}$ Chairman Powell noted leakage of sensitive information as a recurring problem: "I've done a slow burn over (my) last three years [at the FCC because of the leaks]” (Ross 2000). Likewise Commissioner Susan Ness noted that leaking “market-sensitive nonpublic information” could not only interfere with the FCC's internal processes but could inappropriately affect markets as well (FCC 00-365, see footnote 2). 


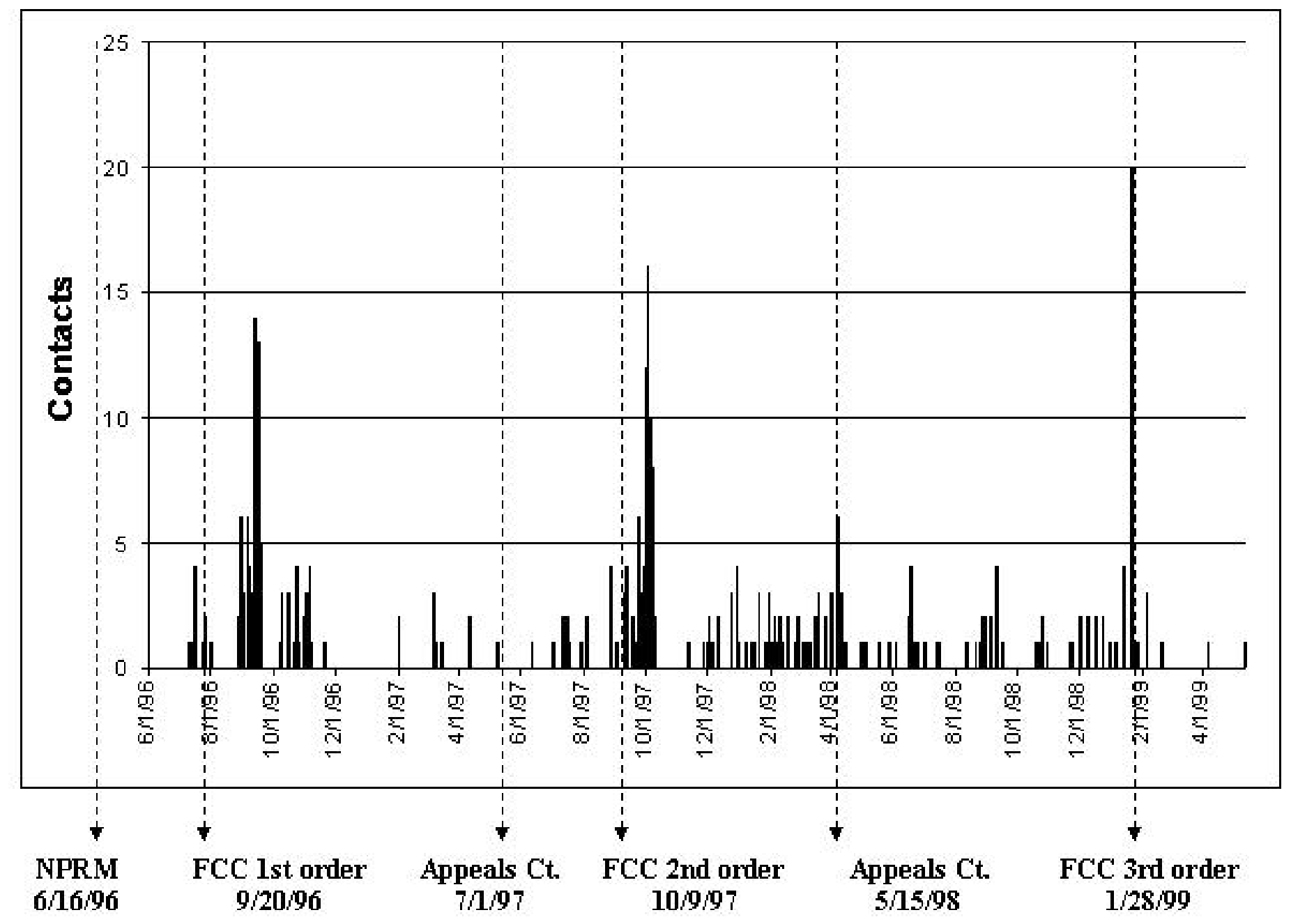

Figure 1: Total Payphone Compensation Lobbying 


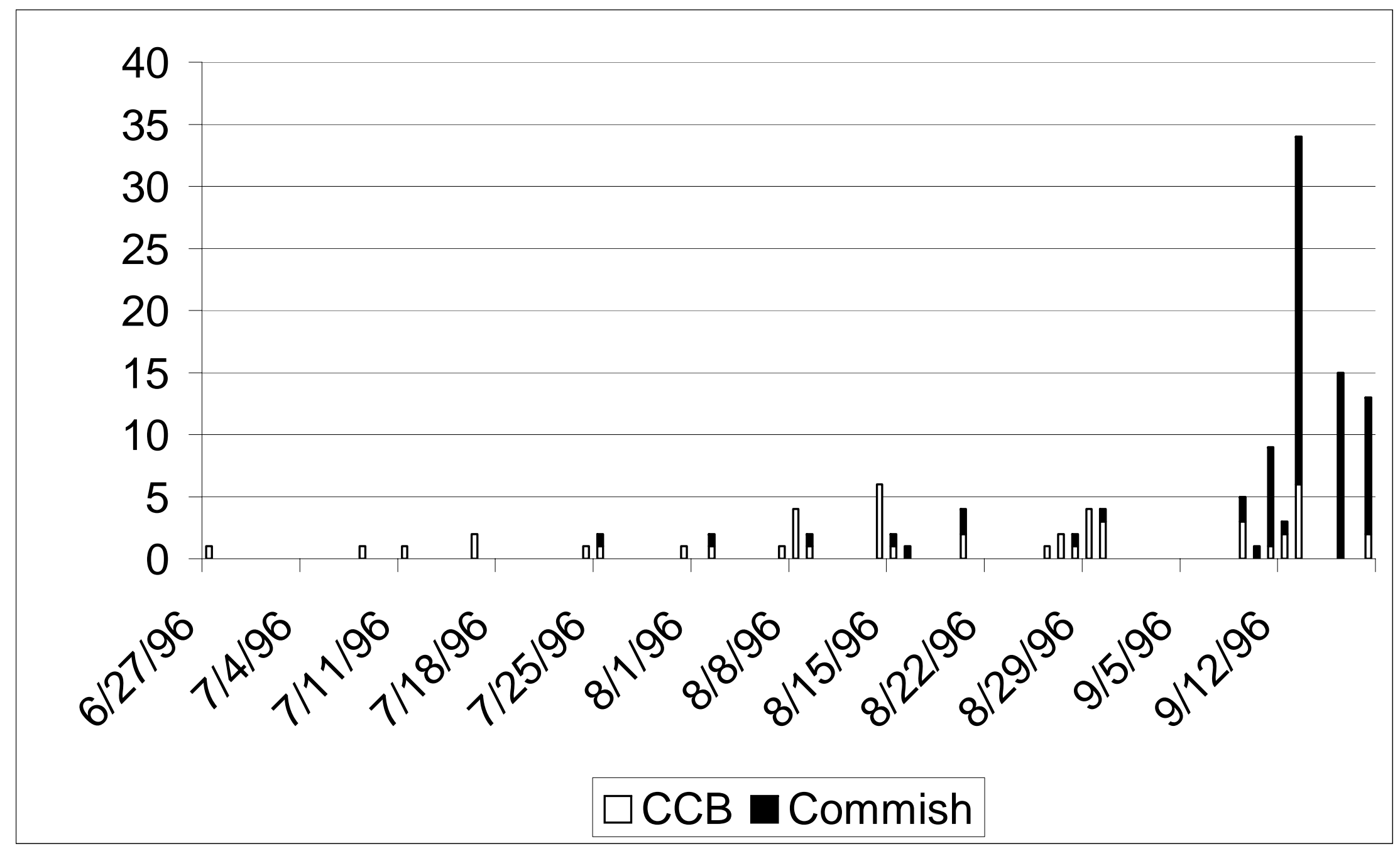

Figure 2a: Common Carrier vs. Commissioner Lobbying 


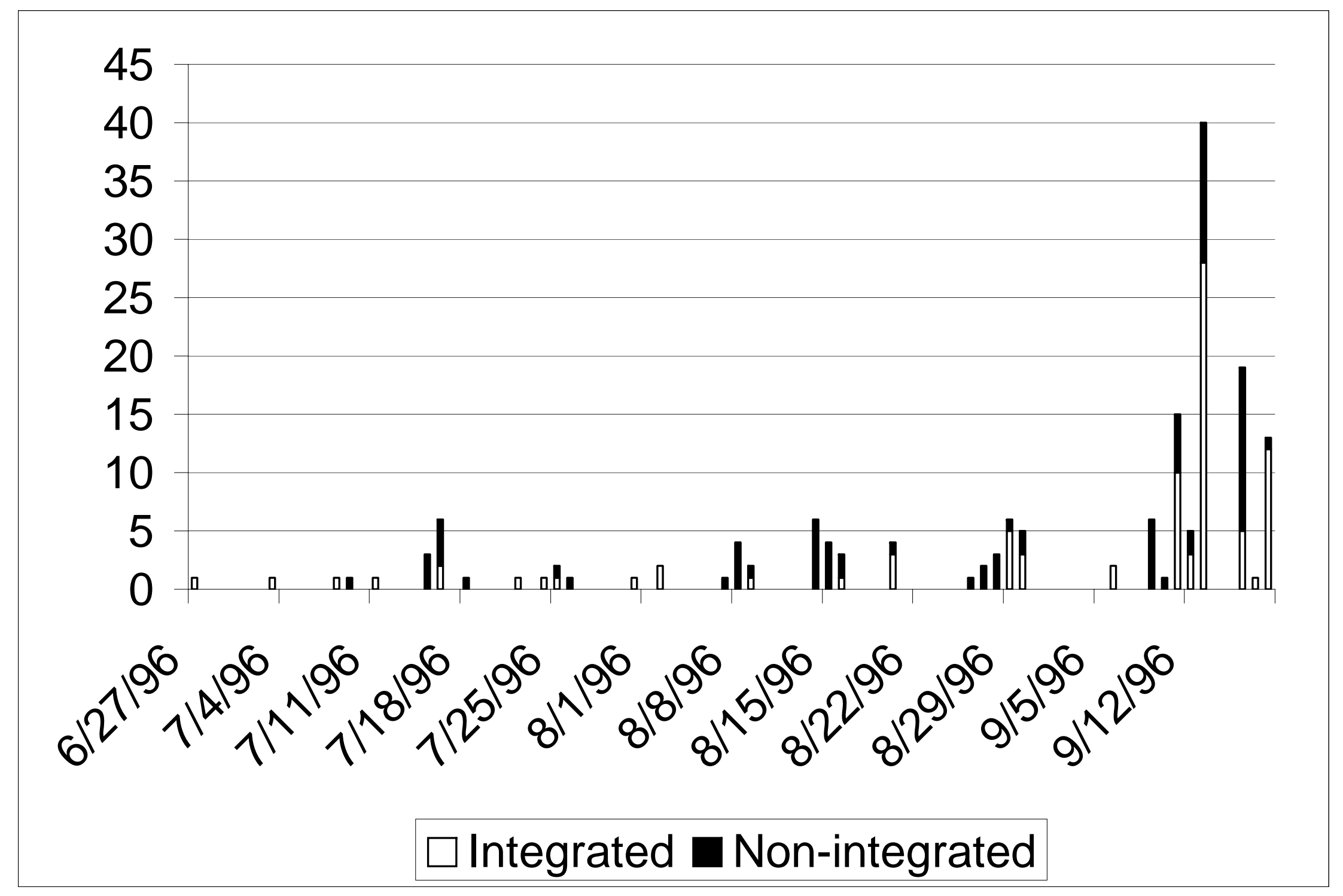

Figure 2b: Integrated vs. Non-integrated Lobbying 


\begin{tabular}{ccccc}
\hline & TABLE 1: DESCRIPTIVE STATISTICS & & \\
\hline Variable & Mean & Std. Dev. & Min & Max \\
VERTICAL INT & 0.71 & 0.46 & 0 & 1 \\
DAYS & 84.20 & 22.26 & 33 & 105 \\
POSITION & 0.85 & 0.35 & 0 & 1 \\
COUNT & 5.69 & 5.81 & 0 & 17 \\
RBOC & 0.17 & 0.38 & 0 & 1 \\
IXC & 0.09 & 0.29 & 0 & 1 \\
COMMISSIONER & 0.15 & 0.36 & 0 & 1 \\
COMPENSATION AMOUNT & 0.59 & 0.49 & 0 & 1 \\
INTERLATA & 0.41 & 0.49 & 0 & 1 \\
COMPENSATION METHOD & 0.65 & 0.48 & 0 & 1 \\
OTHER & 0.04 & 0.20 & 0 & 1 \\
\hline
\end{tabular}


TABLE 2: ECONOMETRICS RESULTS

\begin{tabular}{|c|c|c|c|c|c|c|}
\hline \multicolumn{7}{|c|}{ Dependent Variable: VERTICAL INT = 1 if integrated; 0 if outsourced } \\
\hline & $\underline{\text { Model } 1}$ & $\underline{\text { Model } 2}$ & $\underline{\text { Model } 3}$ & $\begin{array}{c}\text { Model } 4 \\
\frac{\text { Post-Order/Pre- }}{\text { Court Decision }}\end{array}$ & $\underline{\text { Model } 5}$ & $\begin{array}{l}\text { Model } 6 \\
\text { Full Sample with }\end{array}$ \\
\hline$\underline{\text { Variable }}$ & $\underline{\text { Issue Variables }}$ & Full Model & $\underline{\text { Reconsideration }}$ & Lobbying & Full Sample & Period Dummies \\
\hline $\begin{array}{c}\text { COMPENSATION } \\
\text { AMOUNT }\end{array}$ & $\begin{array}{l}1.176^{\star * \star} \\
(0.434)\end{array}$ & $\begin{array}{l}1.417^{\star \star} \\
(0.618)\end{array}$ & $\begin{array}{c}0.67 \\
(0.815)\end{array}$ & $\begin{array}{c}0.336 \\
(0.287)\end{array}$ & $\begin{array}{l}0.275^{\star} \\
(0.170)\end{array}$ & $\begin{array}{l}0.327^{*} \\
(0.168)\end{array}$ \\
\hline INTERLATA & $\begin{array}{l}0.646^{\star \star} \\
(0.291)\end{array}$ & $\begin{array}{c}0.135 \\
(0.425)\end{array}$ & & $\begin{array}{l}-0.829 * * \\
(0.355)\end{array}$ & $\begin{array}{l}-0.066 \\
(0.259)\end{array}$ & $\begin{array}{l}-0.155 \\
(0.290)\end{array}$ \\
\hline $\begin{array}{c}\text { COMPENSATION } \\
\text { METHOD }\end{array}$ & $\begin{array}{l}-1.064^{\star \star \star} \\
(0.407)\end{array}$ & $\begin{array}{l}-1.384^{\star *} \\
(0.597)\end{array}$ & $\begin{array}{l}-0.537 \\
(0.477)\end{array}$ & $\begin{array}{l}-0.691^{\star \star *} \\
(0.231)\end{array}$ & $\begin{array}{l}-0.551^{\star \star \star} \\
(0.161)\end{array}$ & $\begin{array}{l}-0.619^{\star \star \star} \\
(0.170)\end{array}$ \\
\hline OTHER & $\begin{array}{l}-1.215^{\star *} \\
(0.539)\end{array}$ & $\begin{array}{l}-1.323^{* *} \\
(0.521)\end{array}$ & & $\begin{array}{l}-0.435^{\star *} \\
(0.197)\end{array}$ & $\begin{array}{l}-0.073 \\
(0.120)\end{array}$ & $\begin{array}{l}-0.041 \\
(0.120)\end{array}$ \\
\hline DAYS & & $\begin{array}{l}-0.013 \\
(0.008)\end{array}$ & $\begin{array}{c}0.009 \\
(0.020)\end{array}$ & $\begin{array}{l}-0.001^{\star * *} \\
0.000\end{array}$ & $\begin{array}{l}-0.001^{\star * *} \\
0.000\end{array}$ & $\begin{array}{l}-0.001^{* * *} \\
0.000\end{array}$ \\
\hline POSITION & & $\begin{array}{l}-0.615 \\
(0.696)\end{array}$ & $\begin{array}{l}-0.286 \\
(0.521)\end{array}$ & $\begin{array}{l}-0.922^{\star * \star} \\
(0.296)\end{array}$ & $\begin{array}{l}-0.548^{\star * *} \\
(0.190)\end{array}$ & $\begin{array}{l}-0.615^{\star \star *} \\
(0.207)\end{array}$ \\
\hline COUNT & & $\begin{array}{l}-0.053^{\star *} \\
(0.026)\end{array}$ & $\begin{array}{l}-0.101^{*} \\
(0.060)\end{array}$ & $\begin{array}{c}0.003 \\
(0.014)\end{array}$ & $\begin{array}{l}-0.005 \\
(0.008)\end{array}$ & $\begin{array}{l}-0.004 \\
(0.009)\end{array}$ \\
\hline RBOC & & $\begin{array}{l}1.239 * \star * \\
(0.396)\end{array}$ & $\begin{array}{l}-0.221 \\
(0.691)\end{array}$ & $\begin{array}{l}1.405^{\star \star *} \\
(0.315)\end{array}$ & $\begin{array}{l}1.214^{\star \star *} \\
(0.214)\end{array}$ & $\begin{array}{l}1.229 \star \star \star \\
(0.237)\end{array}$ \\
\hline IXC & & $\begin{array}{l}-0.318 \\
(0.778)\end{array}$ & & $\begin{array}{c}0.861^{\star \star \star} \\
(0.325)\end{array}$ & $\begin{array}{c}0.829 \star \star \star \\
(0.166)\end{array}$ & $\begin{array}{l}0.735^{\star \star \star} \\
(0.165)\end{array}$ \\
\hline COMMISSIONER & & $\begin{array}{l}0.631^{\star *} \\
(0.272)\end{array}$ & & $\begin{array}{c}0.157 \\
(0.288)\end{array}$ & $\begin{array}{l}0.759 * \star \star \\
(0.168)\end{array}$ & $\begin{array}{l}0.716^{\star \star \star} \\
(0.160)\end{array}$ \\
\hline
\end{tabular}




\begin{tabular}{|c|c|c|c|c|c|c|}
\hline RECONSIDERATION & & & & & & $\begin{array}{l}-0.563^{\star} \\
(0.298)\end{array}$ \\
\hline $\begin{array}{c}\text { POST-ORDER/PRE- } \\
\text { TRIAL }\end{array}$ & & & & & & $\begin{array}{l}-0.043 \\
(0.314)\end{array}$ \\
\hline PRE-ORDER II & & & & & & $\begin{array}{l}-0.059 \\
(0.283)\end{array}$ \\
\hline PRE-ORDER III & & & & & & $\begin{array}{c}0.198 \\
(0.290)\end{array}$ \\
\hline CONSTANT & $\begin{array}{l}1.683^{\star *} \\
(0.843)\end{array}$ & $\begin{array}{l}2.377^{\star *} \\
(1.065)\end{array}$ & $\begin{array}{l}-0.873 \\
(3.568)\end{array}$ & $\begin{array}{c}1.824^{\star \star *} \\
(0.340)\end{array}$ & $\begin{array}{c}0.990^{\star * *} \\
(0.185)\end{array}$ & $\begin{array}{c}1.198^{\star \star \star} \\
(0.238)\end{array}$ \\
\hline $\begin{array}{l}\text { Log-Likelihood } \\
\text { n }\end{array}$ & $\begin{array}{c}-72.52 \\
150\end{array}$ & $\begin{array}{l}-80.16 \\
150\end{array}$ & $\begin{array}{c}-29.68 \\
47\end{array}$ & $\begin{array}{c}-164.00 \\
393\end{array}$ & $\begin{array}{c}-494.25 \\
934\end{array}$ & $\begin{array}{c}-488.95 \\
934\end{array}$ \\
\hline
\end{tabular}

